\title{
How Do Foliar Application of Melatonin and L-Tryptophan Affect Lettuce Growth Parameters Under Salt Stress?
}

\author{
Fatih Hancı, ${ }^{1, a, *}$, Gizem Tuncer ${ }^{1, b}$ \\ ${ }^{I}$ Department of Horticulture, Agriculture Faculty, Erciyes University, 38280 Kayseri, Turkey
}

*Corresponding author

A R T I C L E I N F O
Research Article
Received : 02/12/2019
Accepted : 12/02/2020

Accepted : 12/02/2020

A B S T R A C T

The aim of this study was to investigate the effects of exogenous Melatonin $(100,300$ and $500 \mu \mathrm{M})$ and L-tryptophan $(125,250,375 \mathrm{ppm})$ applications on some growth parameters of lettuce plants grown under salt stress. The study was carried out under semi-controlled greenhouse conditions in spring (March/April) season. The exogenous applications to lettuce plants were carried out two times as foliar spraying. Salt stress was generated by adding $\mathrm{NaCl}(0 \mathrm{mM}, 100 \mathrm{mM}, 200 \mathrm{mM})$ to irrigation water. The complete randomized design was used with three replications in this experiment. At the end of the study, it was found that the highest doses of exogenous applications had the highest effect on the parameters of the number of leaves, salinity necrosis, fresh leaf weight, fresh root weight, and total surface area of lettuce plants under $200 \mathrm{mM}$ salinity condition. When the effects of the subtract

Keywords:

Abiotic Stress on these values were compared, the effect of melatonin was found to be more pronounced. Leaf Melatonin

Seedling

Tolerance

L-Tryptophan width, leaf length, and leaf surface temperature values were not affected by the external application. These values only changed depending on salt concentration. As a result of the study, it was concluded that the application of $500 \mu \mathrm{M}$ melatonin significantly increased salt tolerance in lettuce plants. However, in order to reach a more general conclusion, the dose ranges and genotype/variety numbers should be increased.

Türk Tarım - Gıda Bilim ve Teknoloji Dergisi, 8(4): 960-964, 2020

\section{Yapraktan Uygulanan Melatonin ve L-Triptofan, Tuz Stresi Altındaki Marulun Büyüme Parametrelerini Nasıl Etkiler?}

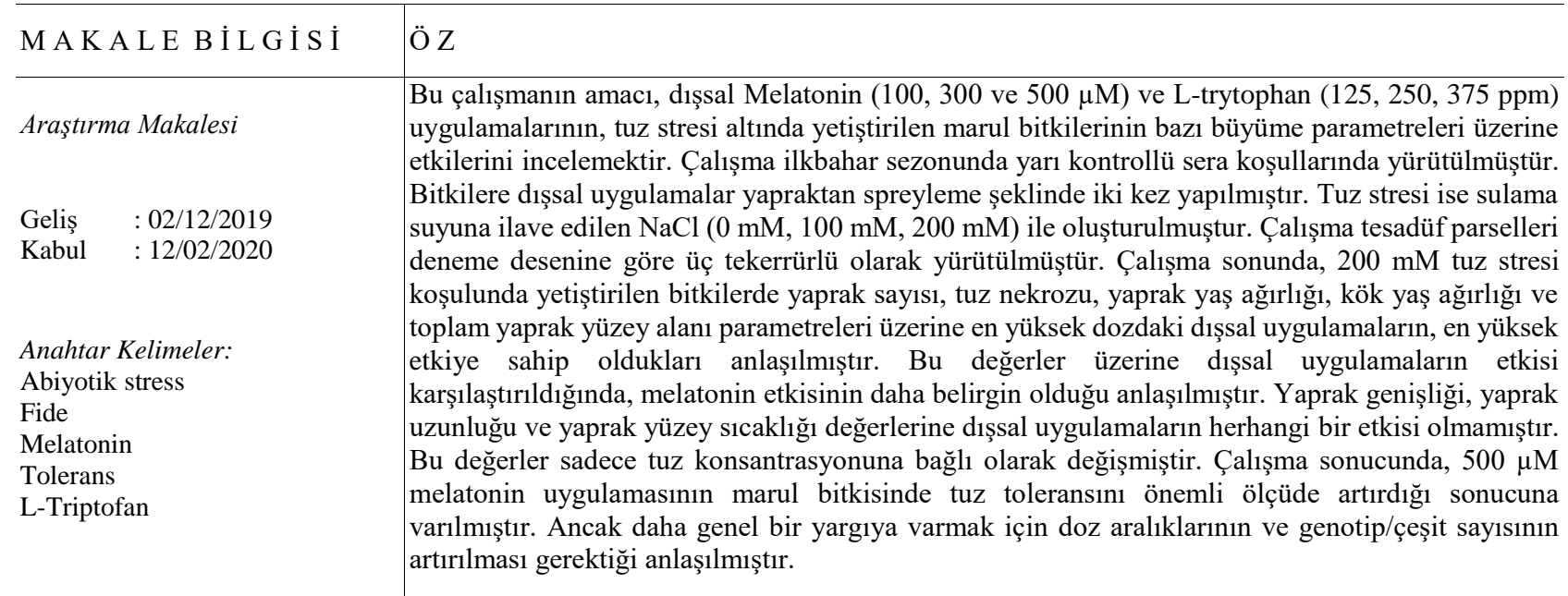




\section{Introduction}

Lettuce (Lactuca sativa L.) is a one-year cool climate vegetable of the genus Lactuca of the Compositae (Asteraceae) family. Lettuce is among the most leaf consumed vegetables in the world. Lettuce has been cultivated for approximately 2500 years. Lettuce, which has been cultivated and fondly consumed for many years, can be found in markets throughout the year (Vural et al., 2000). According to the most recent data of the United Nations Food and Agriculture Organization (FAO), worldwide lettuce (and chicory) production was approximately 26.866.557 tonnes in 2017 from 1.227.358 hectares. According to the same data, Turkey produces 490.423 tonnes of lettuce (and chicory) annually, and it ranks as the 8th biggest producer (Anonymous, 2019).

Different ecological conditions of Turkey allow the cultivation of many types of vegetables. As a result of these advances, Turkey is the fourth-largest vegetable producer country after the United States, China, and India. Vegetable production has an important place in Turkey's economy. Also, Turkey is among the countries selfsufficient in terms of vegetable production (Yanmaz et al., 2015). However, this production potential is under various risks. Especially in greenhouse cultivation, soils have been faced with the threat of pollution and fatigue because of intensive plant production, monoculture applications, intensive use of chemicals, and the absence of natural rainfall. Stress factors in plants are grouped as biotic (viruses, bacteria, fungi, insects, herbivores, rodents, parasitic plants) and abiotic (salt, water, temperature, light, gases, minerals, radiation, etc.) stress factors (Ashraf and Foolad, 2007; Uyanık et al., 2014). The salinity which is one of the abiotic stresses is one of the most important reasons for the decrease in the yield of agricultural land (Tuteja, 2007). Salinity affects about 227 million hectares of irrigated agricultural land (Tuteja, 2007; Çulha and Çakırlar, 2012). Turkey is faced with 1.5 million hectares of land salinity. $60 \%$ of these lands are classified as saline, $19.6 \%$ as medium saline and $0.4 \%$ as alkaline (Kendirli et al., 2005). Salinity stress is an important issue for agricultural production and there are many different strategies to eliminate salinity stress (Ekbic et al., 2017). Exogenous application of plant growth regulators (PGRs) has proven quite successful in alleviating different types of abiotic stresses in plants (Ahmad et al., 2019).

Melatonin (Mel) was first obtained from the cattle brain gland (epiphysis) in 1958 (Lerner et al., 1958). Since the pineal tissue is found only in the nervous system of vertebrates and melatonin functions hormonal structure, this compound was initially thought to be a neural hormone (neurohormone) and synthesized only in the pineal tissue (Gundy et al., 1976). Melatonin was found in plants for the first time in 1995 by two different research groups as a result of independent research (Dubbels et al., 1995; Hattori et al., 1995). After the presence of plants, a growing number of researches have been conducted in different fruits, cereals, vegetables, seeds, medicinal and aromatic plants and ornamental and wild plant species (Paredes et al., 2009). Melatonin synthesis starts from tryptophan in all living organisms including plants, algae, and bacteria. Tryptophan is a compound from which the synthesis begins not for melatonin, but also serotonin and indole-3 acetic acid. The most widely accepted pathway for the synthesis of melatonin from tryptophan is TryptophanTryptamine-Serotonin-Melatonin (Murch and Saxena, 2002).

L-tryptophan (3-indolylalanine) (L-tr), discovered by the British chemist Frederick Gowland Hopkins in 1901. It is an essential amino acid not only for plants but also for animals, humans and certain bacteria (Frankenberger and Arshad, 1991). It is a biologically active precursor molecule of auxin and therefore increases the level of auxin in plant tissues when exogenously applied. Although the positive effects of L-tr application on the germination and growth performance of various plants have been reported by several researchers (Abbas et al., 2013; Antony et al., 2017), there are no studies demonstrating their effects on lettuce.

While several studies have been published investigating the effects of different plant growth regulators and seed pretreatments on lettuce grown under abiotic stress, no studies have been found to investigate the role of L-tr or Mel applications together on growth parameters under salinity stress conditions. Therefore, the main objective of this study was to evaluate the effect of different L-tr and Mel concentrations on several parameters of lettuce plants under salinity conditions.

\section{Material and Methods}

The study was carried out at the Erciyes University, Faculty of Agriculture, Kayseri, Turkey period of MarchMay, 2019. The experiment was conducted in semicontrolled greenhouse conditions with 3 replications by a completely randomized design.

All cultivation continued for about two months, during which the minimum temperature was $10^{\circ} \mathrm{C}$ and the maximum temperature was $18^{\circ} \mathrm{C}$. Lettuce (Lactuca sativa L. cv. Grise Maraichère') was used as plant material. Seeds of lettuce were sown in viols which filled with perlite/peat (1:1) mixture. Twenty days old seedlings were then transplanted into two-liter pots. These pots were filled with 1.8 liters of perlite/peat/ soil mixture (1:1:1). Salt stress treatments were carried out as described by Ahmed et al. (2019) with little modifications. This experiment consisted of three treatments of $\mathrm{NaCl}(0 \mathrm{mM}, 100 \mathrm{mM}, 200 \mathrm{mM})$. The application of saline irrigation began one week after the seedlings were transplanted. The pots of each group were then divided into seven subgroups. Different levels of $\operatorname{Mel}(100,300$ and $500 \mu \mathrm{M})$ and L-tr $(125,250,375$ ppm) were applied to sub-groups. These agents were applied two times to 34 and 41 days old plants, as a foliar spray. All plants were sprayed with $30 \mathrm{ml}$ of solution. Irrigation continued for five days' periods until the end of the trial (60 days). All agronomic applications were made as required. Data on twelve traits were recorded on an individual basis from three plants randomly chosen in each treatment. A scale of 0-5 was used in order to express the visible signs of damage caused by salt stress on lettuce plants. At the end of the experiment, standard discs were taken from middle-aged and young leaves of lettuce plants. The fresh weights of these discs and the fresh weights of all leaves were recorded. The total leaf area of the plant 
was calculated using the obtained data. To determine the fresh and dry weights ( $\mathrm{g} / \mathrm{plant}$ ) of the leaves and roots, each plant was weighed on a sensitive balance, then reweighed after drying in a $65^{\circ} \mathrm{C}$ oven for 48 hours.

Leaf temperatures were measured from the three points of the widest leaf with an infrared thermometer. Statistical analysis was conducted using the JMP software. The data from the experiment were subjected to a general analysis of variance (ANOVA).

\section{Results and Discussion}

The combined analysis of variance indicated that the effect of salinity statically significant for all measured characters. Furthermore, the interaction between experimental factors was significant for eight traits: number of leaves (LN), leaf color (LC), salinity necrosis $(\mathrm{SN})$, total leaf fresh weight $\left(\sum \mathrm{FLW}\right)$, total fresh root weight $\left(\sum F R W\right)$, total leaf surface area ( $\sum$ LSA), total dry leaf weight $\left(\sum \mathrm{DLF}\right)$, and total dry root weight $\left(\sum \mathrm{DRW}\right)$ (Table 1 and 2). Generally, all morphological parameters were reduced by increased salinity level except for salinity necrosis and leaf surface temperature.

The number of leaves ranged from 8.50 to 18.50 per plant. Although the number of leaves decreased with respect to the degree of the salinity, the doses of Mel and L-tr affected the severity of this decreasing. In lettuce plants not irrigated with salt water, the highest number of leaves was obtained in $250 \mathrm{ppm}$ L-Tryptophan application.
In the highest salt stress condition $(200 \mathrm{mM})$, application of $500 \mu \mathrm{M} \mathrm{Mel}$ and $375 \mathrm{ppm}$ L-tr resulted in a significant increase in the number of leaves compared to the control. $\mathrm{Xu}$ and Mou (2015) reported a decrease in fresh mass and dry mass values of 178 lettuce cultivars depend on salt stress. The present study showed a gradual reduction in plant weight and average leaf number with increasing salt concentrations consistent with the study as previously reported (Al-Maskri et al., 2010, Garrido et al., 2014)

Leaf color was determined visually. For this purpose, the color darkness was scored linearly from 1 to 5 . While the color was darker in the plants without salt stress (4.07), the color was lightened due to increased salt concentration (3.64). Necrosis in leaves due to salinity stress was also visually scored. During this process, stress-free plants were used as control. In terms of these traits, $500 \mu \mathrm{M}$ Melatonin and 375 ppm L-Tryptophan applications showed very positive results under $200 \mathrm{mM}$ salinity conditions. When the decreases in the averages due to increasing salt dose were examined, the most dramatic decrease was observed in $\sum$ FLW and TLSA values (84\%). In plants without salt stress, only the lowest doses of exogenous treatments caused an increase in $\sum F L W$ values. No significant change was observed in $100 \mathrm{mM}$ salt stress depending on applications. However, at the $100 \mathrm{~mm}$ stress conditions, $500 \mu \mathrm{M}$ Melatonin and $375 \mathrm{ppm}$ L-Tryptophan applications significantly increased weight of fresh leaves values compared to control in the same group.

Table 1. Some growth parameters of lettuce plants at different salinity conditions

\begin{tabular}{|c|c|c|c|c|c|c|c|}
\hline Salinity & Treatment & $\mathrm{LN}$ & $\mathrm{LC}$ & $\mathrm{SN}$ & $\overline{\sum F L W}$ & $\sum$ FRW & $\sum \mathrm{LSA}$ \\
\hline \multirow{8}{*}{0} & 0 & $14.50^{\mathrm{A}-\mathrm{E}}$ & $5.0^{\mathrm{A}}$ & $0^{\mathrm{D}}$ & $101.00^{\mathrm{B}}$ & $7.45^{\mathrm{CD}}$ & $2077.29^{\mathrm{B}}$ \\
\hline & $100 \mu \mathrm{M} \mathrm{Mel}$ & $16.50^{\mathrm{AB}}$ & $4.0^{\mathrm{B}}$ & $0^{\mathrm{D}}$ & $131.22^{\mathrm{A}}$ & $8.60^{\mathrm{BC}}$ & $2698.83^{A}$ \\
\hline & $300 \mu \mathrm{M}$ Mel & $14.50^{\mathrm{A}-\mathrm{E}}$ & $4.0^{\mathrm{B}}$ & $0^{\mathrm{D}}$ & $106.65^{\mathrm{B}}$ & $9.38^{\mathrm{B}}$ & $2193.39^{\mathrm{B}}$ \\
\hline & $500 \mu \mathrm{M} \mathrm{Mel}$ & $13.00^{\mathrm{B}-\mathrm{F}}$ & $4.0^{\mathrm{B}}$ & $0^{\mathrm{D}}$ & $107.13^{\mathrm{B}}$ & $5.91^{\mathrm{DE}}$ & $2203.36^{\mathrm{B}}$ \\
\hline & 125 ppm L-tr & $13.50^{\mathrm{B}-\mathrm{E}}$ & $3.5^{\mathrm{BC}}$ & $0^{\mathrm{D}}$ & $135.04^{\mathrm{A}}$ & $11.83^{\mathrm{A}}$ & $2777.29^{\mathrm{A}}$ \\
\hline & 250 ppm L-tr & $18.50^{\mathrm{A}}$ & $4.0^{\mathrm{B}}$ & $0^{\mathrm{D}}$ & $92.65^{\mathrm{B}}$ & $5.66^{\mathrm{DE}}$ & $1905.55^{\mathrm{B}}$ \\
\hline & 375 ppm L-tr & $13.00^{\mathrm{B}-\mathrm{F}}$ & $4.0^{\mathrm{B}}$ & $0^{\mathrm{D}}$ & $90.22^{\mathrm{B}}$ & $4.61^{\mathrm{E}-\mathrm{G}}$ & $1855.57^{\mathrm{B}}$ \\
\hline & \multicolumn{2}{|l|}{ Mean } & 4.07 & 0.00 & 109.13 & 7.63 & 2244.47 \\
\hline \multirow{8}{*}{$\begin{array}{l}200 \\
\mathrm{mM}\end{array}$} & 0 & $16.00^{\mathrm{A}-\mathrm{C}}$ & $4.0^{\mathrm{B}}$ & $0^{\mathrm{D}}$ & $60.09^{C}$ & $3.73^{\mathrm{F}-\mathrm{I}}$ & $1235.88^{\mathrm{C}}$ \\
\hline & $100 \mu \mathrm{M} \mathrm{Mel}$ & $15.50^{\mathrm{A}-\mathrm{D}}$ & $4.0^{\mathrm{B}}$ & $0^{\mathrm{D}}$ & $61.45^{\mathrm{C}}$ & $5.26^{\mathrm{EF}}$ & $1263.85^{\mathrm{C}}$ \\
\hline & $300 \mu \mathrm{M} \mathrm{Mel}$ & $14.50^{\mathrm{A}-\mathrm{E}}$ & $4.0^{\mathrm{B}}$ & $0.5^{\mathrm{CD}}$ & $51.33^{\mathrm{CD}}$ & $3.14^{\mathrm{G}-\mathrm{J}}$ & $1055.61^{\mathrm{CD}}$ \\
\hline & $500 \mu \mathrm{M} \mathrm{Mel}$ & $14.00^{\mathrm{B}-\mathrm{E}}$ & $4.0^{\mathrm{B}}$ & $0.5^{\mathrm{CD}}$ & $64.80^{\mathrm{C}}$ & $4.46^{\mathrm{E}-\mathrm{G}}$ & $1332.75^{\mathrm{C}}$ \\
\hline & 125 ppm L-tr & $13.50^{\mathrm{B}-\mathrm{E}}$ & $4.0^{\mathrm{B}}$ & $0.7^{\mathrm{D}}$ & $58.81^{\mathrm{C}}$ & $4.56^{\mathrm{E}-\mathrm{G}}$ & $1209.56^{\mathrm{C}}$ \\
\hline & $250 \mathrm{ppm} \mathrm{L-tr}$ & $12.00^{\mathrm{C}-\mathrm{G}}$ & $4.0^{\mathrm{B}}$ & $0.5^{\mathrm{CD}}$ & $39.28^{\mathrm{DE}}$ & $2.94^{\mathrm{G}-\mathrm{J}}$ & $807.78^{\mathrm{DE}}$ \\
\hline & 375 ppm L-tr & $11.50^{\mathrm{D}-\mathrm{H}}$ & $3.5^{\mathrm{BC}}$ & $1.5^{\mathrm{BC}}$ & $67.98^{\mathrm{C}}$ & $4.11^{\mathrm{E}-\mathrm{H}}$ & $1398.16^{\mathrm{C}}$ \\
\hline & Mean & 13.86 & 3.93 & 0.53 & 57.68 & 4.03 & 1186.23 \\
\hline \multirow{8}{*}{$\begin{array}{l}400 \\
\mathrm{mM}\end{array}$} & 0 & $8.50^{\mathrm{GH}}$ & $3.5^{\mathrm{BC}}$ & $3.5^{\mathrm{A}}$ & $6.85^{\mathrm{H}}$ & $2.42^{\mathrm{H}-\mathrm{J}}$ & $140.79^{\mathrm{H}}$ \\
\hline & $100 \mu \mathrm{M} \mathrm{Mel}$ & $7.50^{\mathrm{H}}$ & $3.0^{\mathrm{C}}$ & $3.5^{\mathrm{A}}$ & $9.76^{\mathrm{GH}}$ & $0.52^{\mathrm{K}}$ & $200.63^{\mathrm{GH}}$ \\
\hline & $300 \mu \mathrm{M} \mathrm{Mel}$ & $10.50^{\mathrm{E}-\mathrm{H}}$ & $3.5^{\mathrm{BC}}$ & $3.5^{\mathrm{A}}$ & $18.50^{\mathrm{F}-\mathrm{H}}$ & $1.88^{\mathrm{I}-\mathrm{K}}$ & $380.39^{\mathrm{F}-\mathrm{H}}$ \\
\hline & $500 \mu \mathrm{M} \mathrm{Mel}$ & $15.00^{\mathrm{A}-\mathrm{D}}$ & $4.0^{\mathrm{B}}$ & $1^{\mathrm{CD}}$ & $35.38^{\mathrm{D}-\mathrm{F}}$ & $4.35^{\mathrm{E}-\mathrm{G}}$ & $727.57^{\mathrm{D}-\mathrm{F}}$ \\
\hline & 125 ppm L-tr & $9.00^{\mathrm{F}-\mathrm{H}}$ & $4.0^{\mathrm{B}}$ & $1.5^{\mathrm{BC}}$ & $13.66^{\mathrm{GH}}$ & $1.72^{\mathrm{JK}}$ & $280.85^{\mathrm{GH}}$ \\
\hline & $250 \mathrm{ppm} \mathrm{L-tr}$ & $10.50^{\mathrm{E}-\mathrm{H}}$ & $3.5^{\mathrm{BC}}$ & $2.5^{\mathrm{B}}$ & $14.35^{\mathrm{GH}}$ & $1.63^{\mathrm{JK}}$ & $295.14^{\mathrm{GH}}$ \\
\hline & 375 ppm L-tr & $14.00^{\mathrm{B}-\mathrm{E}}$ & $4.0^{\mathrm{B}}$ & $0.5^{\mathrm{CD}}$ & $26.14^{\mathrm{E}-\mathrm{G}}$ & $2.84^{\mathrm{G}-\mathrm{J}}$ & $537.63^{\mathrm{E}-\mathrm{G}}$ \\
\hline & Mean & 10.71 & 3.64 & 2.29 & 17.81 & 2.19 & 366.14 \\
\hline \multirow{3}{*}{$F$ ratios } & Salinity & $14.47 *$ & $5.60 *$ & $47.71 *$ & $428.86^{*}$ & $131.57^{*}$ & $428.86^{*}$ \\
\hline & Hormone & 0.55 & 1.27 & 1.61 & $5.15^{*}$ & $5.17 *$ & $5.15^{*}$ \\
\hline & Salinity $\times$ Hormone & $3.10 *$ & $2.57 *$ & $3.58^{*}$ & $4.77 *$ & $7.71 *$ & $4.77 *$ \\
\hline
\end{tabular}

Means in a column followed by the different letters are significantly different at the various levels as determined by LSD test. CV: coefficient of variation, LSD: least significance difference. P <0.01. Mel: Melatonin, L-tr: L-Tryptophan, LN: Number of leaves, LC: Leaf color; SN: Salinity necrosis, $\sum$ FLW: Total fresh leaves weight, $\sum$ FRW: Total root fresh weight; $\sum$ LSA: Total surface area. 
Table 2. Some growth parameters of lettuce plants at different salinity conditions

\begin{tabular}{|c|c|c|c|c|c|c|c|}
\hline Salinity & Treatment & $\mathrm{LN}$ & $\mathrm{LC}$ & $\mathrm{SN}$ & $\sum F L W$ & $\sum \mathrm{FRW}$ & $\sum \mathrm{LSA}$ \\
\hline \multirow{8}{*}{ 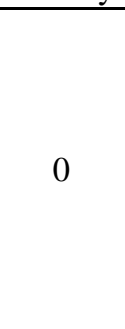 } & 0 & $98.11^{\mathrm{AB}}$ & $8.49^{\mathrm{C}-\mathrm{E}}$ & 14.75 & 20.00 & 7.50 & 143.97 \\
\hline & $100 \mu \mathrm{M} \mathrm{Mel}$ & $124.52^{\mathrm{A}}$ & $9.77^{\mathrm{A}-\mathrm{D}}$ & 14.40 & 20.50 & 7.50 & 165.36 \\
\hline & $300 \mu \mathrm{M} \mathrm{Mel}$ & $108.35^{\mathrm{A}}$ & $7.90^{\mathrm{D}-\mathrm{F}}$ & 14.40 & 21.50 & 10.00 & 169.49 \\
\hline & $500 \mu \mathrm{M} \mathrm{Mel}$ & $101.40^{\mathrm{A}}$ & $7.35^{\mathrm{D}-\mathrm{F}}$ & 14.50 & 20.75 & 9.50 & 208.30 \\
\hline & 125 ppm L-tr & $108.70^{\mathrm{A}}$ & $12.08^{\mathrm{A}}$ & 14.00 & 19.00 & 6.50 & 143.61 \\
\hline & $250 \mathrm{ppm} \mathrm{L-tr}$ & $107.72^{\mathrm{A}}$ & $9.72^{\mathrm{A}-\mathrm{D}}$ & 14.45 & 20.50 & 7.50 & 151.41 \\
\hline & 375 ppm L-tr & $108.40^{\mathrm{A}}$ & $10.90^{\mathrm{A}-\mathrm{C}}$ & 14.65 & 18.00 & 8.00 & 103.16 \\
\hline & Mean & 108.17 & 9.46 & $14.45^{\mathrm{B}}$ & $20.04^{\mathrm{A}}$ & $8.07^{\mathrm{A}}$ & $155.04^{\mathrm{A}}$ \\
\hline \multirow{8}{*}{$\begin{array}{l}200 \\
\mathrm{mM}\end{array}$} & 0 & $111.63^{\mathrm{A}}$ & $7.46^{\mathrm{D}-\mathrm{F}}$ & 14.65 & 15.00 & 5.25 & 78.48 \\
\hline & $100 \mu \mathrm{M} \mathrm{Mel}$ & $105.04^{\mathrm{A}}$ & $11.48^{\mathrm{AB}}$ & 14.55 & 17.50 & 6.25 & 82.12 \\
\hline & $300 \mu \mathrm{M} \mathrm{Mel}$ & $44.25^{\mathrm{CD}}$ & $4.61^{\mathrm{G}-\mathrm{I}}$ & 14.75 & 15.50 & 5.50 & 96.15 \\
\hline & $500 \mu \mathrm{M} \mathrm{Mel}$ & $116.04^{\mathrm{A}}$ & $9.79^{\mathrm{A}-\mathrm{D}}$ & 14.45 & 15.50 & 5.50 & 90.22 \\
\hline & 125 ppm L-tr & $114.19^{\mathrm{A}}$ & $8.99^{\mathrm{B}-\mathrm{D}}$ & 14.85 & 11.50 & 4.50 & 125.30 \\
\hline & $250 \mathrm{ppm} \mathrm{L-tr}$ & $64.75^{\mathrm{BC}}$ & $6.12^{\mathrm{E}-\mathrm{G}}$ & 14.30 & 16.25 & 6.50 & 72.49 \\
\hline & 375 ppm L-tr & $23.52^{\mathrm{DE}}$ & $4.69^{\mathrm{G}-\mathrm{I}}$ & 15.00 & 14.00 & 5.50 & 67.89 \\
\hline & \multicolumn{2}{|l|}{ Mean } & 7.59 & $14.65^{\mathrm{B}}$ & $15.04^{\mathrm{B}}$ & $5.57^{\mathrm{B}}$ & $87.52^{\mathrm{B}}$ \\
\hline \multirow{8}{*}{$\begin{array}{l}400 \\
\mathrm{mM}\end{array}$} & 0 & $7.78^{\mathrm{E}}$ & $4.04^{\mathrm{G}-\mathrm{I}}$ & 15.55 & 8.75 & 2.50 & 16.75 \\
\hline & $100 \mu \mathrm{M} \mathrm{Mel}$ & $10.13^{\mathrm{E}}$ & $2.36^{\mathrm{I}}$ & 14.95 & 9.00 & 2.75 & 27.62 \\
\hline & $300 \mu \mathrm{M} \mathrm{Mel}$ & $22.69^{\mathrm{DE}}$ & $11.57^{\mathrm{A}}$ & 14.70 & 13.50 & 5.00 & 48.53 \\
\hline & $500 \mu \mathrm{M} \mathrm{Mel}$ & $35.33^{\mathrm{C}-\mathrm{E}}$ & $6.01^{\mathrm{E}-\mathrm{G}}$ & 14.70 & 7.25 & 2.25 & 38.24 \\
\hline & 125 ppm L-tr & $26.84^{\mathrm{DE}}$ & $4.06^{\mathrm{G}-\mathrm{I}}$ & 14.95 & 11.50 & 4.75 & 38.36 \\
\hline & 250 ppm L-tr & $21.81^{\mathrm{DE}}$ & $3.35^{\mathrm{HI}}$ & 15.25 & 8.50 & 3.25 & 41.86 \\
\hline & 375 ppm L-tr & $23.98^{\mathrm{DE}}$ & $5.76^{\mathrm{F}-\mathrm{H}}$ & 15.35 & 9.50 & 3.50 & 27.80 \\
\hline & Mean & 21.22 & 5.31 & $15.06^{\mathrm{A}}$ & $9.71^{\mathrm{C}}$ & $3.43^{\mathrm{C}}$ & $34.17^{\mathrm{C}}$ \\
\hline \multirow{3}{*}{ F ratios } & Salinity & $108.11 *$ & $40.58 *$ & $10.29 *$ & $68.71 *$ & $50.00^{*}$ & 123.44* \\
\hline & Hormone & $3.73 *$ & $2.20 *$ & 1.59 & 1.21 & 1.27 & 3.61 \\
\hline & Salinity $\times$ Hormone & $4.38 *$ & $11.67 *$ & 0.86 & 1.13 & 1.44 & 1.81 \\
\hline
\end{tabular}

Means in a column followed by the different letters are significantly different at the various levels as determined by LSD test. CV: coefficient of

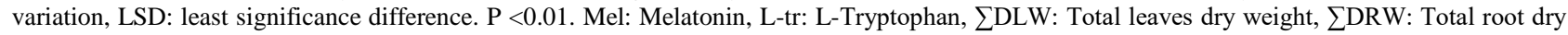
weight, LST: Leaves surface temperatures, LL: length of largest leaf, LW: Widht of largest leaf, MLSA: Mean leaf surface area

In the salt-free group, total leaves surface area (TLSA) values were slightly increased with the lowest doses of exogenous applications, but no difference was observed in increasing doses. The results obtained at the highest salt dose $(200 \mathrm{mM})$ in the TLSA examination showed parallels with other traits, and the highest external dose applications (500 $\mu \mathrm{M}$ Melatonin and 375 ppm L-Tryptophan) gave the best results. The fresh weights of the roots were not compatible with the dose increases of external applications in the salt-free medium. However, in the presence of severe salt stress, these values increased in parallel with the doses of exogenous applications.

Seed germination, fresh and dry weight of shoot, and root weight of lettuce have been affected both by ionic and osmotic effects due to salinity (Barassi et al., 2006). In a study carried out by Ahmed et al. (2019), depending on increasing salt doses, shoot length, root length, total plant weight, and leaf number were significantly decreased. The results obtained in our study are in parallel with these findings. Increased doses of melatonin increased leaf dry weight (DLW) at $200 \mathrm{mM}$ salt stress conditions. However, no similar effect was observed in L-tr doses.

External applications had no effect on the surface temperature of the leaves. The difference between these values was statistically the same at 0 and $100 \mathrm{mM}$ salt concentrations. LST increased slightly at $200 \mathrm{mM}$ salt concentration. The results obtained in the leaf length (LL), leaf width (LW), and mean leaf surface area (MLSA) values are similar to LST. Exogenous applications did not have any effect on these results. Only at the highest salt dose, negative changes were observed. The effects of exogenous melatonin applied to lettuce seedlings under salt stress were investigated by Wie et al. (2018). At the end of the study, it was determined that spraying melatonin on the leaves increased the stomatal conductance, transpiration rate, and net photosynthetic rate of the plants. The act of melatonin on the photosynthetic features involved in nitrate assimilation under the excess nitrate stress in lettuce was detected by Zhou et al. (2019). The findings indicated that supplementation of melatonin decreased the nitrate content both in leaves and roots. Also the fresh and dry weights of seedlings were dramatically increased depending on melatonin.

There are few studies investigating the effects of L-tr on plants. In the study of Khan et al. (2019), the effect of three different amino acids (L-methionine, L- glycine, and L-tryptophan) on different growth parameters of lettuce was investigated. L-methionine significantly increased the growth performance, whereas growth using L-tryptophan and L-glycine decreased.

Even though varied reports about the effect of Mel and L-tr on growth parameters of different plant species were published, this is the first study in which two subtracts are tested together under the salinity conditions for lettuce. The highest stress condition in the study was determined as irrigation with $200 \mathrm{mM} \mathrm{NaCl}$ using previous studies. No diseases, pests or physiological disorders were encountered during cultivation except for those caused by salt stress. At the end of the study, the highest dose of melatonin and LTryptophan had the highest positive effect on the number 
of leaves, salinity necrosis, fresh leaf weight, fresh root weight, and total surface area of lettuce plants under severe stress conditions. The effect of melatonin in all these traits was higher than L-Tryptophan. However, since the number of doses was limited to three, the results could not be tested in higher doses. Therefore, further studies need to determine higher doses. In the dry weight values of the leaves, only the highest dose of melatonin had a positive effect. Results of root dry weight were different than the others. For this feature, the middle dose of melatonin showed the highest effect, but there was a serious decrease in the increasing dose. Some physical dimensions of the leaves (width and length) decreased only depending on the dose of salt stress but were not affected by external applications. Similarly, leaf surface temperature only reacted to salt stress. These results need to be examined further by checking environmental factors. In addition, in order to reach a more general judgment, the dose range of external applications should be expanded and the number of genotypes /varieties used should be increased.

\section{Acknowledgments}

This work was supported by the Research Fund of the Erciyes University. Project Number: FLO-2018- 8572.

\section{Kaynaklar}

Abbas SH, Sohail M, Saleem M, Mahmood T, Aziz I, Qamar M, Majeed A, Arif M 2013. Effect of L-tryptophan on plant weight and pod weight in chickpea under rainfed conditions. Sci., Tech. and Dev, 32(4): 277-280.

Ahmed S, Ahmed S, Roy SK, Woo SH, Sonawane KD, Shohael AM. 2019. Effect of salinity on the morphological, physiological and biochemical properties of lettuce (Lactuca sativa L.) in Bangladesh. Open Agriculture. 4: 361-373

Ahmad B, Zaid A, Sadiq Y, Bashir S, Wani SH. 2019. Role of Selective Exogenous Elicitors in Plant Responses to Abiotic Stress Tolerance. In Plant Abiotic Stress Tolerance (pp. 273 290). Springer, Cham.

Al-Maskri A, Al-Kharusi L, Al-Miqbali H, Khan MM. 2010. Effects of salinity stress on growth of lettuce (Lactuca sativa) under closed-recycle nutrient film technique, Int. J. Agric. Biol., 12, 377-380

Anonymous, 2019. FAO Agricultural Statistical Database. http://faostat.org (Accessed: 20.11.2019)

Antony E, Sridhar K, Kumar V. 2017. Effect of chemical sprays and management practices on Brachiaria ruziziensis seed, production. Field Crops Research, 211: 19-26.

Ashraf M, Foolad MR. 2007. Roles of Glycine Betaine and Proline in İmproving Plant Abiotic Stress Resistance. Environmental Experimental Botany, 59: 206-216.

Barassi CA, Ayrault G, Creus CM, Sueldo RJ. Sobrero, MT. 2006. Seed inoculation with Azospirillum mitigates $\mathrm{NaCl}$ effects on lettuce, Sci. Hortic. (Amsterdam), 2006, 109, 8-14

Çulha Ş, Çakırlar H. 2012. The Effect of Salinity on Plants and Salt Tolerance Mechanisms. AKU J. Sci,11, 11-34.

Dubbels R, Reiter RJ, Klenke E, Goebel A, Schnakenberg E, Ehlers C, Schiwara HW, Schloot W. 1995. Melatonin in Edible Plants Identified by Radioimmunoassay and by High Performance Liquid Chromatography Mass Spectrometry. J of Pineal Res, 18 (1): 28-31.
Ekbic E, Cagıran C, Korkmaz K, Kose MA, Aras V. 2017. Assessment of watermelon accessions for salt tolerance using stress tolerance indices. Ciência e Agrotecnologia, 41(6), 616-625.

Frankenberger W, Arshad M. 1991. Yield response of watermelon and muskmelon to L-tryptophan applied to the soil. Hort Science, 26(1): 35-37.

Garrido Y, Tudela JA, Marín A. Mestre T, Martínez V, Gil MI. 2014. Physiological, phytochemical and structural changes of multi-leaf lettuce caused by salt stress, J Sci Food Agric, 94, $1592-1599$

Gundy GC, Ralph CL, Wurst GZ. 1976. Parietal Eye in Lizards: Zoogeograsphical Correlates. The Anatomical Record, 190: 671-673.

Hattori A, Migitaka H, Masayaki I, Itoh M, Yamamoto K, OhtaniKaneko R, Hara M, Suzuki T, Reiter RJ. 1995. Identification of Melatonin in Plant Seed its Effects on Plasma Melatonin Levels and Binding to Melatonin Receptors in Vertebrates. Biochem Mol Biol Int, 35: 627-634.

Kendirli B, Cakmak B, Ucar Y. 2005 Salinity in the Southeastern Anatolia project (GAP), Turkey: Issues and Options. Journal of Irrigation and Drainage Engineering 54(1): 115-122

Khan S, Yu H, Li Q, Gao Y, Sallam BS, Wang H, Liu P, Jiang W. 2019. Exogenous Application of Amino Acids Improves the Growth and Yield of Lettuce by Enhancing Photosynthetic Assimilation and Nutrient Availability, Agronomy, 9(5), 266-271

Lerner AB, Case JD, Takahashi Y, Lee TH, Mori W. 1958. Isolation of Melatonin, the Pineal Factor that Lightness Melanocytes. Journal of American Chemical, Society, 80: 2587-2592.

Murch SJ, Saxena PK. 2002. Melatonin: a Potential Regulator of Plant Growth and Development? Invitro Cellular Developmental Biology Plant, 38: 531-536.

Paredes SD, Korkmaz A, Manchester LC, Tan DX, Reiter RJ. 2009. Phytomelatonin: a Review. Journal of Pineal Research, 60: 57-69.

Tuteja N. 2007. Mechanisms of High Salinity Tolerance in Plants. Methods in Enzymology, 428, 419-438.

Uyanık M, Kara ŞM, Korkmaz K. 2014. Determination of responses of some winter canola (Brassica napus L.) cultivars to salt stress at germination period. Tarim Bilimleri Dergisi, 20(4), 368-375.

Xie Y, Sun G, Liao H, Tang Y. 2018. Effects of Exogenous Melatonin on Photosynthetic Physiology of Lettuce Seedlings under Salt Stress, Advances in Engineering Research, volume $162,81-84$

Vural H, Eşiyok D. Duman İ. 2000. Kültür sebzeleri (sebze yetiştirme). Ege Üniversitesi Ziraat Fakültesi Bahçe Bitkileri Bölümü, Bornova-İzmir, 440.

Yanmaz R, Duman İ, Yaralı F, Demir K, Sarıkamış G, Sarı N, Balkaya A, Kaymak HÇ, Akan S ve Özalp R (2015) "Sebze Üretiminde Değişimler ve Yeni Arayışlar”, Türkiye Ziraat Mühendisliği VIII. Teknik Kongresi, Bildiriler Kitab1-1, 579605, 12-16 Ocak 2015, Ankara.

Yu S, Wang W, Wang B. 2012. Recent progress of salinity tolerance research in plants. Russian Journal of Genetics. 48:497-505.

Zhou X, Yang T, Jiang Z, He Z, Zou Z. 2019. Regulation of melatonin on chlorophyll fluorescence and nitrate accumulation in lettuce seedlings under excess nitrate stress. IOP Conf. Series: Earth and Environmental Science, 330,1-5 